AGNIESZKA ZABIELSKA

\title{
PLAC SZCZEPAŃSKI PRZEZ WIEKI
}

Historia placu Szczepańskiego wiąże się bezpośrednio z kilkoma ważnymi dla miasta okresami, wywierającymi również znaczny wpływ na kościól św. Szczepana, od którego pochodzi nazwa placu. Niewątpliwie miejsce to powiązane jest z dziejami Krakowa, które podobnie jak cale miasto przechodziło przez różne procesy zmian i regulacji.

Pierwszym ważnym dla Krakowa momentem była lokacja w 1257 roku, dzięki której miasto zyskało nowy lad przestrzenny, a także w wyniku lokacji ustalił się status gospodarczy, prawny i obronny miasta. Jej skutki odczuwalne były także znacznie później, doprowadzając do pełnego rozwoju Krakowa. „Ten okres rozwoju miasta nadał Krakowowi niezatarty charakter średniowiecznego miasta, zważywszy, że większość monumentalnych budowli (szczególnie kościołów) wznoszono w stylu gotyckim w ciagu XIV i XV wieku"1. Kraków został podzielony na tzw. cztery kwartały. Jeden z nich, kwartał sławkowski, obejmował podówczas ulicę Sławkowska, Szczepańską i inne aż po ulicę Szewską. W wieku XIV był on najsłabiej zabudowany, jednak już wiek później zaszly spore zmiany w układzie przestrzennym tego kwartału ${ }^{2}$. W mieście wiele budowli mieszkalnych, także tych umieszczonych przy placu Szczepańskim, stanowiły drewniane domy, więc mogły ulec zniszczeniu w czasie pożarów, późniejsze już, XV-wieczne, budowane były $z$ kamienia, zwane odtąd kamienicami.

Kolejnym ważnym, ale ciężkim okresem w dziejach miasta, który istotnie przyczynił się do zmiany wyglądu także placu, był najazd Szwedów i Siedmiogrodzian. Spowodował on upadek Krakowa w latach 1655-1657.

W tym czasie zniszczone zostały przedmieścia Krakowa, spaleniu uległo wówczas wiele budowli i kamienic. Kraków był miastem wyniszczonym przez kontrybucje, kwaterunki, a niedługo potem także przez huragan, który nawiedził miasto w roku 1703. Morowe powietrze w latach 1707-1708, liczne przemarsze wojsk w czasie wojny sukcesyjnej z lat 1733-1735 oraz poniekąd wojna siedmioletnia $z$ lat 1756-1763 były dla miasta sporym ciężarem i mimo że wojna toczyła się w państwach ościennych, to Kraków odczuwał jej reperkusje. Wiele budynków

$'$ K. P i e radzka, Rozkwit średniowiecznego Krakowa w XIV i XVw., [w:] J. D a b r ow s k i, Studia nad rozwojem miasta, Kraków 1957, s. 143.

${ }^{2}$ Kwartały-linie zabudowy miejskiej, które największe znaczenie miały przy poborze podatku miejskiego zwanego szosem - A. B o c hnak, Kraków gotycki, [w:] J. D ąb rowsk i, Kraków jego dzieje i sztuka, Warszawa 1965, s. 97. 
było rozebranych i zdewastowanych, „bo gdy która kamienica dla nieznośnych ciężarów została bez gospodarza, żołdaki generała rozbierali dachy, powaly, belki wyrąbowali, drzwi brali kraty wyłamywali, same tylko gołe mury zostawując, a nie tylko kamienicom czynili, ale i mury okolo miasta podobnym także sposobem rujnowali i baszty murowane i ganki wokolo murów i co tylko na murach od dawna było",

W 1732 r. władze miasta, chcąc zapobiec dalszej dewastacji substancji mieszkaniowej oraz kompletnej degradacji Krakowa, wydały rozporządzenie o następującej treści ,urząd radziecki krakowski zapobiegając takiemu oszpeceniu miasta Krakowa jakie się dzieje przez upadanie coraz kamienic, tak w Rynku jako i po ulicach, przestrzega wszystkich dziedziców, posesorów i jakikolwiek interes albo prawo do tychże kamienic spadłych, pustek i placów mających, aby się do reparacji onychże poczuwali, bez omieszkania oneż reparowali, murowali i budowali się czego jeżeli nie uczynią dziedzictwa wszelakiego prawa odsądzeni będą i wszystkie kamienice spadłe w konfiskatę na skarb JKM"4.

Następnym trudnym etapem w dziejach Krakowa jak i placu Szczepańskiego były czasy zaborów, chociaż, pierwsze lata, 1796-1809, to jakby okres poprawy stanu gospodarczego miasta. U schyłku XVIII w. Kraków został powiększony o Kleparz, Kazimierz i Garbary i podzielony na cztery cyrkuły. Pierwszy z nich, w którym znalazł się obecny plac Szczepański, obejmował Rynek, ulicę Grodzka, Bracka, Kanonicza, zamek, św. Józefa, Szeroka, wjazd publiczny od bramy Grodzkiej i Pobocznej, Stolarską, Sienną, Szpitalną, Mikołajską, Różaną, i wjazd publiczny od Bramy Nowej, Floriańską, św. Jana, Podmurze z przecznicami, wjazd od Bramy Floriańskiej, ulicę Żydowską (obecnie św. Tomasza), św. Szczepana z przecznicami, wjazd od Bramy Sławkowskiej, ulicę Świecką (obecnie Szewska), Wiślną, Gołębią z przecznicami i wjazd od Bramy Wiślnej i Świeckiej. W XIX wieku usunięte mury miejskie zmieniły układ miasta.

Jak sądzono, były one przeszkodą w lepszej komunikacji. Przybyło ulic i przejść, a powstanie placu Szczepańskiego skróciło ulicę Szczepańska, która przedtem dochodziła do murów miejskich. Austriacy chcieli doprowadzić Kraków do stanu innych nowożytnych miast monarchii naddunajskiej. Sprzedawano nie przynoszące dochodu budowle, nie troszcząc się przy tym o ich wartość zabytkowa. Likwidowano przykościelne cmentarze - walcząc $\mathrm{z}$ brudem i nieczystościami. Podobnie czyniono $\mathrm{z}$ wieloma zabytkowymi kościołami, stojącymi od wieków w różnych miejscach Krakowa. Do celów porządkowych służyć miał specjalny Komitet Upiększania Miasta. Wszelkie elementy tchnące średniowieczem należało usuwać z budynków.

Domy budowano już tylko z twardych materiałów. Stwarzano wyjątkowe warunki dla wlaścicieli, którzy zdecydowali się na przebudowe lub wrybudowanie zupełnie nowej posiadłości. „Zachęceni korzyściami dla budujących nowe domy $\mathrm{z}$ twardego materiału lub podobne, opustoszałe $\mathrm{z}$ gruntu reparujących, zapewnionymi mieszkańcy częstokroć nad możność swoją przykładają się do ich upięknienia"6".

${ }^{3}$ J. M u c zk ow s k i, Dawne warownie krakowskie, „Rocznik Krakowski” nr XIII, Kraków 1911, s. 45.

${ }^{4}$ WAP Archiwum Miasta Krakowa, rkps 3563.

${ }^{5}$ D. R e d e row a, Powstanie Krakowa nowożytnego, [w:] J. D ą b r ow s k i, Studia nad rozwojem miasta, Kraków 1957, s. 251.

${ }^{6}$ S. K a w e c k i, Opis miasta Krakowa w obrębie okopów w r. 1836, s. 46. 
Plac Szczepański, podobnie jak i cały Kraków, przechodził zmiany, o których wspomina Ambroży Grabowski: „Kto przez ostatnie lat 20, poprzedzające rok 1840 Krakowa nie widział, a dawniejszy jego stan pamięta, temu, gdy go teraz odwiedzi, trudno jest pojąć, jakie w upięknieniu nade wszystko przedmieść nastąpiły zmiany.

Wprawdzie i samo miasto wewnątrz zyskało niezmiernie na uporządkowaniu, gdyż wszystkie domy wyreperowane, kolorową powłoka facjaty powleczone mając, nie rażą więcej oka widokiem dawnych pustek, na wpół zwalonych kamienic i nie zamieszkałych drugich i trzecich pietter, a nade wszystko $\mathrm{w}$ ulicach ustronniejszych, które ja jeszcze w dosyć smutnym stanie w czasie przybycia mego do Krakowa w r. 1797 pamiętam, a którego domy już od zajęcia przez rząd austriacki w r. 1796 wlaściciele reperować zaczęli"?

W roku 1858, za prezydentury Józefa Dietla, Kraków został podzielony na osiem dzielnic. W pierwszej o nazwie Śródmieście znalazł się plac Szczepański. Częściowo też została zrealizowana regulacja ulic, placów, rozbudowa kanalizacji.

W Krakowie w 1908 r. powstało Biuro dla gruntów pofortyfikacyjnych, a w 1910 r. Biuro regulacji miasta. Wówczas w mieście stały już budynki zrealizowane w stylu wiedeńskiej secesji.

W obecnym kształcie Krakowa zlokalizowanych jest kilka placów, które jeszcze w wieku XIX placami nie były, gdyż teren ich zajmowały gotyckie kościoły. Do nich należą: plac Św. Ducha, którego nazwa pochodzi od mieszczącego się tutaj kościoła wraz z klasztorem i szpitalem wybudowanym w XIV w., a zburzonym w 1892 roku, plac Marii Magdaleny, przy którym wznosił się kościół św. Marii Magdaleny z XIV w. stanowiący prebendę uniwersytecką przynależna prawnikom, a wyburzony w roku 1811, plac Słowiański, na którym od 1390 do 1817 roku stał wybudowany dzięki św. Jadwidze i Kazimierzowi Wielkiemu kościól dla benedyktynów obrządku słowiańskiego, plac Wszystkich Świętych, przy którym stał kościół od XIII w. pod tym samym wezwaniem, wyburzony w dwóch etapach. Świątynię zburzono w latach 1835-1838, a jej wieżę w roku 1843 i wreszcie plac Szczepański, który jest przedmiotem niniejszego opracowania ${ }^{8}$.

Lokalizację placu opisuje Stanisław Tomkowicz: „Pierwotnie placu tutaj nie było, była tylko grupa luźnych zabudowań na prostokącie między zachodniemi końcami ulic Szczepańskiej i dzisiejszej św. Tomasza, oraz między północnem przedłużeniem ul. dziś Jagiellońskiej a murem miejskim zachodnim, który w XIX wieku ustapił miejsca plantacjom""?

Nazwa zarówno placu jak i ulicy Szczepańskiej wiąże się bezpośrednio z ulokowaniem w tym miejscu kościoła pod wezwaniem św. Szczepana. Dzisiejszy plac w północno-zachodniej części miasta był terenem przy murach obronnych Krakowa wybudowanych na polecenie Leszka Czarnego już w 1298 roku. Od strony Plant Kraków otoczony został murami obronnymi z 39 basztami, wśród których w okolicach dzisiejszego placu Szczepańskiego znajdowały się trzy baszty.

${ }^{7}$ A. Gra bows k i, Wspomnienia, t. II, [w:] Biblioteka Krakowska, t. 41, Kraków 1909, s. $180-182$.

${ }^{8}$ D. R e d e row a, Powstanie Krakowa nowożytnego, [w:] J. D ą b row s k i, Studia nad rozwojem miasta, Kraków 1957, s. 267. K. P i e r a d z k a, Rozkwit średniowiecznego Krakowa, [w:] J. D ą b row s k i, Studia nad rozwojem miasta..., dz. cyt., s. 166, 168, 254.

${ }^{9} \mathrm{~S}$. T o m k ow i c z, Ulice i place Krakowa w ciagu dziejów, ich nazwy i zmiany postaci, Kraków 1926 , s. 98. 
Pierwsza $\mathrm{z}$ nich to baszta czerwonych garbarzy ulokowana w stronę bramy Szewskiej. Miała dawne przyziemie z łamanego wapienia, na którym oparty był półkolisty bęben ze strzelnicami i gotyckimi laskowaniami datowanymi na wiek $\mathrm{XV}$. Krenelaż mógł być nadbudowany koroną muru podtrzymującego więźbę strzelistego dachu. U szczytu znajdowała się kula z dokumentami budowy, przebudowy bądź jej napraw.

Druga z nich to baszta garncarzy osłaniająca kościół św. Szczepana. Zbudowana została na planie prostokąta $\mathrm{z}$ czterospadowym dachem, bez otworów strzelniczych i była typową wieżą obronna. Ponieważ była otynkowana dlatego nie wiadomo, czy była zbudowana $z$ cegły, łamanego wapienia czy piaskowca. Do czasu jej zburzenia nie uległa modernizacji.

Kolejna to okraggła baszta Paśników (wyrabiających pasy, sprzączki i złote tkaniny) zamykała ulicę św. Tomasza. W jej pobliżu znajdował się nowicjat jezuicki. Baszta ta miała kwadratową podstawę z łamanego wapienia, na niej umieszczony był półkolisty bęben opatrzony w otwory dla dział małego kalibru z charakterystycznym rozszerzeniem wnęki na zewnątrz, miał zwieńczenie stożkiem przykryte gontem. Na szczycie znajdowała się pozłacana puszka z dokumentami opisującymi historię baszty.

Ostatnią była baszta Introligatorów i Stelmachów znajdująca się w pobliżu klasztoru i kościoła Reformatów. Baszta miała kwadratową podstawę zbudowaną w XIV w. z lamanego kamienia wapiennego. Wzniesiono także ceglany bęben o dwóch kondygnacjach zaopatrzonych w otwory strzelnicze, podobnie jak w poprzedniej baszcie obniżono wysokość baszty i dano jej strzeliste zwieńczenie. W późniejszym czasie baszty bronili drukarze i księgarze. Posiadała ona ganek obniżający jej stanowiska działowe, co wskazywałoby na jej późniejszą przebudowę ${ }^{10}$.

Pomiędzy dzisiejszym placem biegły dwie ulice: Szczepańska biegnąca regularnie podobnie jak inne krakowskie ulice: Floriańska, św. Jana, Sławkowska, Szewska czy św. Anny, i ulica św. Tomasza zwana wówczas ulicą Żydowską, ze względu na ulokowanie na tym obszarze Żydów, którzy wybudowali tu synagogę, kahał, łaźnię i budynki mieszkalne. Nieco wcześniej Żydzi mieszkali przy ulicy św. Anny, ale w XV wieku zostali przeniesieni w okolice placu Szczepańskiego ${ }^{11}$.

S.Tomkowicz wspomina za A. Grabowskim, że w tym miejscu znajdowała się również furta przez długi czas nie mająca nazwy, która później otrzymała nazwę furty żydowskiej, znajdująca się w pobliżu kościoła św. Szczepana i sąsiadująca $z$ wieżą miejska.

Kościół św. Szczepana w źródłach historycznych zaznaczony jest już na początku XIV w., jak również nieco później u Jana Długosza ${ }^{12}$.W roku 1302 wymieniona jest nazwa ulicy, przy której znajidował się kościół , in Sinte Stephanis Gạsse", z kolei pod rokiem 1310 znajduje się wzmianka o kościele św. Szczepana. O kościele wspomina dokument biskupa Jana Grota z 1327 r. wymieniający grani-

${ }^{10}$ M. T o b i a s z, Fortyfikacje dawnego Krakowa, Kraków 1973, s. 123.

$" 1$ M. B a ł a b a n, Przewodnik po żydowskich zabytkach Krakowa, Kraków 1935, s. 4-5; S. T o m k ow i c z, Ulice i place Krakowa w ciagu dziejów, ich nazwy i zmiany postaci, Kraków 1926, s. 98.

${ }^{12} \mathrm{O}$ zewnętrznym wyglądzie kościoła wspomina Jan Długosz mówiąc, że kościół został wybudowany z cegły: „Ecclesia Sancti Stephani in Cracovia coctolatere murata" - J. D ł u g o s z, Liber Beneficiorum dioecesis Cracoviae, Cracoviae 1864, s. 14. 
ce czterech największych krakowskich parafii: Mariackiej, św. Krzyża, Wszystkich Świętych i św. Szczepana ${ }^{13}$.

Świątynia od czasu powstania najprawdopodobniej ok. 1300 r. do 1802 r., czyli do momentu jej zburzenia, zmieniała swój wygląd dwukrotnie. Początkowo byla świątynią w stylu gotyckim, upodobniając się przy tym do innych krakowskich kościołów: pod wezwaniem św. Krzyża i kościoła św. Marka ${ }^{14}$.

Po sprowadzeniu przez bp. Tomasza Płazę OO. Jezuitów w roku 1579, świątynia zyskała nowy barokowy wystrój wnętrza oraz wygląd fasady ${ }^{15}$.

Ze źródeł pisanych w okresie funkcjonowania parafii na placu Szczepańskim, wynika, że kościół był stosunkowo dużą budowlą, skoro w jego wnętrzu mieściło się łącznie siedem konsekrowanych ołtarzy, a główny ołtarz z obrazem męczeńskiej śmierci św. Szczepana miał ponad 6 metrów wysokości ${ }^{16}$. Kościół jako parafia miał bardzo duży, zasięg wychodząc, już poza teren murów obronnych miasta, gdyż w jej obręb wchodziły okoliczne wsie i przysiółki: Zielonki, Mydlniki, Garbary, Kawiory, Czarna Wieś, Nowa Wieś, Krowodrza, Łobzów, Rząska oraz część Bronowic.

Wspomniane klęski, które nawiedziły Kraków, a także wewnętrzne zaniedbania spowodowały, że kościół św. Szczepana podzielił los doprowadzonych do ruiny wielu krakowskich budowli. Rozporządzeniem gubernialnym z 1802 r. zdecydowano o wyburzeniu świątyni ${ }^{17}$. Przed ostateczną likwidacją dochodziło, do niszczenia sprzętu znajdującego się w świątyni, a także do licytacji wielu wartościowych zabytków, o których donosiły gazety, informując o możliwości zakupu niektórych części jej wyposażenia: „W Krakowie pod wagą miejska znajduje się do sprzedania wielki dzwon z kościoła św. Szczepana"18. Oprócz tego pojawiło się jeszcze jedno ogłoszenie w gazecie, dotyczace już samego faktu zburzenia świątyni: ,kościół za dni ośm zaczną burzyć i koszary będą stawiane na miejscu św. Macieja i św. Szczepana kościołów"19.

Ostatnie nabożeństwo w kościele św. Szczepana odbyło się w dniu $11 \mathrm{X}$ 1801 r., po którym przeniesiono parafię do kościoła Najświętszej Panny Marii na

${ }^{13}$ F. P i e k os ińs k i, J. S zu j s ki, Najstarsze księgi i rachunki miasta Krakowa od $r$. 1300 do 1400, cz. 1, [w:] Monumenta Medii Aevii Historica IV, Kraków 1878, s. 6; F. P i e k o s i ń s k i, Kodeks dyplomatyczny miasta Krakowa 1257-1506, cz. II-IV, [w:] Monumenta Aevii Historica VII, Kraków 1882, s. 499.

${ }_{14}$ Taki kształt świątyni obrazuje plan Kolłątajowski, S. To mk ow i c z, Koltatajowski plan Krakowa z roku 1785 r., "Rocznik Krakowski” IX, 1909, s. 48; A. B o c h n a k, Kraków gotycki, [w:] J. D ą b row s k i, Kraków jego dzieje i sztuka, Kraków 1965, s. 116.

${ }^{15} \mathrm{OO}$. Jezuici nadawali nowy wygląd kościołowi już od roku 1583 , m.in. upodabniając go do świątyni Il Gesu w Rzymie, postarali się również o nowy barokowy wygląd ołtarzy, kaplic czy ławek; barokową fasadę kościoła ukazuje akwarela J. Głogowskiego - M. R o ż e k, Kościól św. Szczepana, „Biuletyn Historii Sztuki” t. 36 (1974), s. 221.

${ }^{16} \mathrm{O}$ ilości ołtarzy, znajdujących się w świątyni, wspomina wizytacja biskupa Radziwiłła z roku 1599, „item habet altaria 7 murata, consecrata”, Cz. S k o w r o n, Akta wizytacji dekanatu krakowskiego z 1599 r., [w:] Materialy do dziejów kościola w Polsce, t. 2, Lublin 1965, s. 53.

${ }^{17} \mathrm{O}$ ówczesnym stanie kościoła mówią słowa: „upada ze starości” zapisane przez Edwarda Muraya w: Bibl. Jag. rkps. 1883, k. 133 i 139 r.; o niezadowalającym wyglądzie świątyni wspomina także wizytacja przeprowadzona przez biskupa A. S. Załuskiego w roku 1748, Archiwum Kapit. Krak. Wizytacja, nr 63, s. 696-697.

18 „Gazeta Krakowska” z dnia 18 XI 1801 r. K. B ą k ow s k i, Kronika krakowska 1796-1848, cz. 1, [w:] Biblioteka krakowska nr 27, Kraków 1905, s. 19-20.

${ }^{19}$ K. B a k o w s k i, Kronika krakowska..., dz. cyt., s. 19. 
Piasku (który zresztą od wieków należał do parafii jako jedna z wielu świątyń filialnych parafii św. Szczepana): ,po południu z kościoła św. Szczepana zakony wszystkie w procesji relikwie świętych w przytomności ludu na Piasek do OO. Karmelitów są przeniesione" ${ }^{, 20}$.

Nieistniejący już kościół św. Szczepana okalał cmentarz ${ }^{21}$, który sięgał ku zachodowi aż do linii kamienicy 1 lub 3, a z południa ku północy od obecnej linii ulicy Szczepańskiej do połowy dzisiejszego budynku Towarzystwa Rolniczego.

W północno-wschodnim narożu cmentarza znajdowała się kaplica św. Macieja i Mateusza, ufundowana przez proboszcza parafii św. Szczepana Stanisława Reja z Kobylan. „Drugi św. Apostolów Macieja i Mateusza, będący filią tamtego znacznie mniejszy, także w stylu gotyckim dźwignięty koło $r$. 1450 hojnością Stanisława Reja podówczas proboszcza z Kobylan, potem kanonika krakowskiego i proboszcza św. Szczepana zmarłego w 1464 r. o 6 ołtarzach, z cmentarzem okolonym murem" ${ }^{\text {"22 }}$. Kościółek św. Macieja i Mateusza został oddany na użytek OO. Jezuitom w $1585 \mathrm{r}$. W świątyni tej znajdowal się m.in. oltarz główny z $1468 \mathrm{r}$. przedstawiający patronów i obraz Matki Bożej Większej z 1616 r.przekazany przez generala zakonu OO. Jezuitów Franciszka Borgiasza. Obraz ten oprawiony był w ramę z 4 złotymi aniołami, 2 koronami, 2 wotami złotymi oraz 65 srebrnymi. Boczne ołtarze zostały dedykowane patronom zakonu, wszystkie zaś udekorowano srebrnymi sukienkami, srebrnymi wotami i relikwiami, srebrnymi lichtarzami, antependiami, obiciami. W zakrystii kościoła znajdowało się 80 ornatów ze złotogłowia, drogich tkanin. W sumie było 59 antependiów, kielichów srebrnych 14 a także srebrna monstrancja i wielki krzyż z postumentem.

Ponadto znajdowało się jeszcze 12 srebrnych lichtarzy, 6 mniejszych, trzy mszały oprawione w srebro, 5 dużych lamp, 6 par ampulek srebrnych, całe srebme antependium do wielkiego ołtarza, 1 kropielnica ${ }^{23}$.

Kaplica św. Macieja i Mateusza posiadała stacje misyjne w Andrychowie, Białej, Markocicach, przy kościele św. Franciszka Ksawerego, Stępocicach, Więcławicach, darowanych przez szlachcica Staszkowskiego w 1616 r. i Zieleńcach, gdzie znajdował sie cudowny obraz Matki Bożej sprowadzony najprawdopodobniej $z$ Konstantynopola ${ }^{24}$.

Ponadto do parafii należał jeszcze nowicjat prowadzony przez OO. Jezuitów, przeniesiony z Braniewa w czerwcu 1586 r., umieszczony w jednej z nieistniejacych już dzisiaj kamienic przy placu Szczepańskim: „W pobliżu tych kościółków, dom mieszkalny proboszcza i trzech wikariuszów i szkoła. Wszystko to stawało

¿ú Tamże, s. 19-20.

${ }^{21}$ Cmentarz był otoczony murem z bramkami, o którym wspomina wizytacja Radziwiłlowska, Cz. S k ow ro n, Akta wizytacji dekanatu krakowskiego 1599 r., [w:] Materiaty do dziejów kościola w Polsce, t. 2, Lublin, 1965, s. 56. Jego istnienie potwierdzają badania archeologiczne przeprowadzone w roku 1964 przez prof. K. Radwańskiego „we wnętrzu i głównie na zewnątrz obiektu (kościoła) odkryto liczne nawarstwiające się groby cmentarza przykościelnego". T. Le n k i ew icz-Rad wańs ka, Sprawozdanie z badań archeologicznych, Muzeum Archeologiczne w Krakowie bez sygn.

${ }^{22}$ S. Z a ł ę s k i, Jezuici w Polsce, t. IV, Kraków 1905, s. 461: wizytacja radziwiłłowska wspomina o kaplicy stojącej przy placu - Cz. S k o w r o n, Akta wizytacji..., dz. cyt., ,s. 63.

${ }^{23}$ Tamże, s. 461.

${ }^{24}$ Encyklopedia wiedzy o Jezuitach, red. O. L. Grzebień, Kraków 1996, s. 322. 
się własnością domu nowicjatu"25. Urządzeniem wyposażenia szkoły zają się ks. Piotr Skarga. Znaczne zaś fundacje na ten cel poczyniła starościna Anna Komarnicka, ofiarując wsie Stępocice i Przecławkę z dniem 21 VI 1585 r. Na potrzeby lokalowe nowicjatu zakupiono kamienicę "Straszkowską" oraz kamienicę zwaną Salomonowska, stojące przy placu Szczepańskim.

Prowincjał zakonu jezuitów O. Campano przebił je i rozszerzył tak, by można było umieścić tam kuchnię, jadalnię, salę nowicjacką zwaną asceterium i sypialnie zwane dormitarzami. Na korytarzu nowicjackim znajdował się obraz Matki Bożej Większej, podobny do tego, jaki znajdował się w kościele Macieja i Mateusza, był przyozdobiony w złoto, srebro i drogie kamienie. W 1583 roku zamieszkali już pierwsi nowicjusze, zaś w roku 1586 przybyło 20 nowicjuszy z Brunbergii, a wraz z nimi mistrz O. Robert Albircombinus, ze Szkocji.

W kolegium przebywało najczęściej od 20 do 50 nowicjuszy, którzy uczestniczyli m.in. w studiach retoryki prowadzonych w latach 1644-1647, studiach filozoficznych prowadzonych na terenie nowicjatu w latach 1757-1758, oraz w zorganizowanej III probacji w latach 1641-1642 i w latach 1658-1659. Co tydzień dwóch nowicjuszy udawało się do kościoła św. Barbary z posługa jak również udawali się na pielgrzymkę jałmużniczą.

Mistrzami nowicjatu byli przeważnie rektorzy domu nowicjatu. W tym samym budynku mieściła się też biblioteka nowicjatu, która dzięki darom Andrzeja Boboli w 1596 r. powiększyla swoje zbiory. Następnie w roku 1600 przekazane zostały woluminy przez ks. Andrzeja Próchnickiego, w roku 1605 przez Kaspra Guttera i Mikołaja Tarnowskiego oraz proboszcza racławickiego w 1657 r. Dokonano także licznych zakupów we Frankfurcie nad Menem. Skatalogowanie zbiorów w 1713 r. pozwoliło ustalić, że biblioteka liczyła w tym czasie 10109 woluminów, głównie ascetycznych. Po kasacie zakonu resztki zbiorów przekazano do kolegium świętego Piotra w Krakowie. Nowicjat miał zapisaną wieś Gorczyce otrzymaną w roku 1611 od Bartłomieja Zebrzydowskiego o wartości 6 tys. zł. W latach 1588, 1591-1592, 1599-1601 ze względu na panującą w Krakowie zarazę przeniesiono nowicjat do Stępocic koło Krakowa, gdzie rektor Pallavicini postawił dość obszerny budynek oraz kaplicę. Kiedy na Kraków natarli Szwedzi, wielu $z$ nich rozlokowało się po kolegium i domach kolegiackich. W związku z niebezpieczeństwem ze strony Szwedów wielu nowicjuszy wysłano na folwarki, by tam pilnowali dóbr przynależnych do nowicjatu.

Podczas wojny tureckiej w 1672 r. znaczna część nowicjuszy z Kamieńca, Lwowa, Przemyśla i Lublina znalazła schronienie w domu nowicjatu św. Szczepana. W tece Ambrożego Grabowskiego pojawia się informacja dotycząca szkoły świętego Szczepana. „W 1776 roku w październiku powracali Moskale z wyprawy tureckiej, a ich załodze z 500 wyznaczono na kwaterę kolegium exjezuickie"26.

Ze znacznie późniejszych wypisów ksiag Wizytacji Szkoły Farnej św. Szczepana, przeprowadzonych w latach 1790-1793, można zauważyć, jak ówcześnie funkcjonowała ta instytucja. Wszystkie wizytacje zostały przeprowadzone na

${ }^{25}$ S. Z a ł ęs k i, Jezuici w Polsce, t. IV, Kraków 1905, s. 461; usytuowanie nowicjatu przedstawiono na planie z doby Sejmu Czteroletniego [w:] J. D ą b row ski, Studia nad rozwojem miasta, Kraków 1957, s. 408.

${ }^{26}$ A. Grabowski, Starożytnicze wiadomości o Krakowie, Archiwum m. Krakowa. Estr. nr 19. 
polecenie Szkoły Głównej Koronnej i rozpoczynały się egzaminowaniem uczniów. Egzaminy obejmowały naukę czytania i pisania. Sprawdzano również wiedzę na podstawie przedmiotów, które wpisane były w program szkoły, takich jak: nauka moralna, arytmetyka, nauka chrześcijaństwa czy znajomość łaciny. Podczas wizytacji zapisano nazwiska ówczesnego seniora szkoły Wilkorzewskiego i dyrektora Dzianottego. Ponadto w notatkach znalazły się informacje o podziale uczniów na dwie klasy. W pierwszej znajdowali się ci, którzy dopiero rozpoczynali naukę, zaś do drugiej klasy uczęszczali uczniowie doskonalący się w ww. przedmiotach. W aktach wizytacji wspomniano o bardzo dobrych postępach uczniów, których dodatkowo zachęcano do nauki poprzez konwokacje mające charakter dyskusji, a dzięki którym można było zapobiec licznym nieobecnościom i nieusprawiedliwionemu lenistwu. Wizytatorzy także omówili stan ówczesnego internatu, w którym mieszkali uczniowie. Część jego mieszkańców dawno skończyła już naukę, lub zrezygnowała $z$ niej i dlatego też powinni jak najszybciej opuścić budynek. Pojawiła się również potrzeba remontu internatu, który miał być wg. wizytatorów wykonany już dawno, zwłaszcza że na jego przeprowadzenie zapisane zostały dobra w kamienicy Arogliwiczów przy placu Szczepańskim. Ogólny poziom szkoły był wysoki i zadowalający wizytatorów, nie odbiegający wynikami od innych podobnych instytucji. W zwiazku ze zniesieniem zakonu Jezuitów w 1773 r. szkołę przejęła Akademia Krakowska, a budynek został zburzony w $1802 \mathrm{r}^{27}$

Większość pierwszych kamienic, jakie stały na placu Szczepańskim, miały ten sam charakter jak pozostałe kamienice krakowskie, ,daleko posunięta jednolitość układu krakowskich kamienic wynika przede wszystkim z regularności układu planowo założonego starego śródmieścia. Mimo pewnych zakrzywień niektórych ciągów ulic nie ma w krakowskim śródmieściu, parcel wyjątkowo i przypadkowo ukształtowanych i wymagających kamienic" ${ }^{28}$. Pierwotne kamienice przy placu były wybudowane w wieku XIV i XV. Zabudowa także i w tym miejscu była murowana $\mathrm{w}$ dolnych partiach $\mathrm{z}$ kamienia, zaś wyższe partie zrobiono $\mathrm{z}$ cegły. Kamienica składała się z frontowego budynku i $\mathrm{z}$ oficyny stojącej na tyłach działki, miała jedynie parter i jedno piętro. Budynek mógł łączyć $z$ oficyną zazwyczaj zadaszony ganek. Niektóre mogły być jeszcze drewniane, zaś te, które stały na narożniku, były już w pełni murowane. W kamienicach tych znajdowały się dwa pomieszczenia frontowe i dwa w partii tylnej. W części z nich zdarzały się wąskie piwnice postawione przed fasadami domów, częściowo zagłębione w ziemię, a częściowo wystawały ponad teren w formie tarasów. Zdarzały się również drewniane nadbudowy, dwuspadowe dachy, kryte dachówkami lub gontem. Wiek XVI przyniósł jedynie przebudowę parterowych sieni na kramy i sklepy ${ }^{29}$.

Czasy przeróbek krakowskich kamienic trzy wieki później w wielu przypadkach nie przyniosły pożądanego efektu, gdyż ,przeważnie dopiero w XIX w. zaczęto budowanie oficyn podłużnych przy bocznych granicach parcel, a jednocze-

${ }^{27}$ Księga Wizyt Szkoty Farney św. Szczepana, Archiwum Państwowe w Krakowie, A.D. 809.

${ }^{28}$ H. J a s i eń s k i, Dawna kamienica krakowska-jej układ $i$ wnętrze, Kraków 1934, s. 16.

${ }^{29}$ M. B or ow i j j ka B irkenmaje rowa, Ksztalt średniowiecznego Krakowa, Kraków 1975, s. 182; W. K o m o r o w s k i, Kamienice krakowskie, [w:] Encyklopedia Krakowa, red. D. Kalisiewicz, Kraków 2001, s. 381. 
śnie nieliczące się z wymiarami podwórz wyciaganie domów w górę, przez nadbudowanie III i IV pięter. Następstwem tego bywa często złe oświetlenie izb tylnych oraz ponure studiowane zacieśnienie wskutek tego jakiegoś nietypowego rozwiązania rzutów powstających na nich podwórz, piętnowane przez ludzi mało świadomych rzeczy jako rzekomo średniowieczne, ale będące w rzeczywistości typowym wytworem XIX w. z jego forsownym dążeniem do symbolicznej pieniężnej wartości użytkowej”30. Podobnie wiele kamienic położonych przy placu Szczepańskim uległo przebudowie, lub całkowitemu wyburzeniu, a na ich miejscu postawiono nowe budynki.

Niedaleko domu nowicjatu OO. Jezuitów (wyburzonego w 1802 r.) w latach 1898-1901 stanął nowy budynek, zaprojektowany przez Franciszka Mączyńskiego zwany Gmachem Towarzystwa Sztuk Pięknych. „Plac Szczepański i jego najbliższe sąsiedztwo stały się w Krakowie głównym terenem, na którym wznoszono architekturę secesyjną i modernistyczną, bowiem pierwszą budowlą w stylu secesji w Krakowie był Gmach Towarzystwa Sztuk Pięknych"31. Zaprojektowany w stylu łączącym elementy klasycyzmu i wiedeńskiej secesji, nawiązywał do wcześniejszych pałaców wystawowych. Zbudowany na planie prostokąta $z$ dwoma ryzalitami w części środkowej elewacji bocznych. Wejście ujęto kolumnowym portykiem zwieńczonym attyką z motywami roślinnymi i trzema reliefowymi tarczami oraz głową Apollona w promienistej aureoli. Rustyfikowane ściany elewacji bocznych wsparte zostały na pilastrach o jońskich kapitelach. Elewacje zarówno wschodnia, jak i zachodnią budynku zdobią nisze $z$ rzeźbionymi popiersiami zasłużonych dla sztuki artystów. W górnej części gmachu ściany obiega płaski fryz reliefowy autorstwa Jacka Malczewskiego.

Od strony placu Szczepańskiego znajduje się szereg postaci w towarzystwie cnót Wiary, Nadziei i Miłości oraz koronacja wieńcem laurowym z udziałem muz i Pegaza. Na elewacji zachodniej umieszczono postacie w towarzystwie Zwatpienia, Rozpaczy, Bólu oraz Pegaza z opuszczonymi skrzydłami ${ }^{32}$.W 1943 r. budynek częściowo został zniszczony przez pożar, ale szybko odrestaurowany.

Pod numerem 1 na placu Szczepańskim pierwotnie mieściło się probostwo kościoła św. Szczepana. W roku 1799 z wykorzystaniem średniowiecznych kamienic powstał wg projektu Szczepana Humberta budynek Starego Teatru, z klasycystyczną fasadą zwróconą ku placowi Szczepańskiemu. Wewnątrz wybudowano parter okolony lożami i balkonami, niewielką scenę i sale redutowe. W takim stanie teatr funkcjonował od 1799 do 1830 r., następnie został zamknięty. W roku 1841 wykupiony został przez władze miasta i powiększony właśnie o kamienicę probostwa kościoła św. Szczepana. Wtedy zyskal wygląd pałacu florenckiego $\mathrm{Z}$ arkadowymi fasadami.

O wyglądzie teatru wspomina także Adam Chmiel, omawiając w swoim opracowaniu obrazy Łukasza Kozakiewicza, które przedstawiały różne budynki przy placu Szczepańskim, w latach 1823-1840. Wówczas według tych obrazów

${ }^{30}$ H. J a s i e ń s k i, Dawna kamienica krakowska.., dz. cyt., s. 20.

${ }^{31}$ H. B l u m, Secesja i akres mtodej Polski, [w:] T. Dobrow olski, Kraków, jego dzieje i sztuka, dz. cyt., s. 519.

${ }^{32}$ R. S o l e w s k i, Franciszek Maczyński i wspólnota sztuki w architekturze miasta realizuje idee "gesamstkuskwerk” we wczesnej twórczości krakowskiego architekta, „Rocznik Krakowski"t. LXI 1995, s. 101. 
budynek teatru przedstawiał się następująco: był nakryty gontowym dachem, fasada miała pilastry i duże wnęki okienne na dole, zaś w środku fasady umieszczono drzwi ze stopniami na zewnątrz. Fasada była pomalowana na kolor zielony ${ }^{33}$.

Obecny wygląd teatr uzyskał w wyniku przebudowy, jaką wspólnie przeprowadzili od 1903 do 1906 r. Tadeusz Stryjeński i F. Mączyński, których zamierzeniem było, powiększenie na tzw. Dom Zabaw z siedzibą Towarzystwa Muzycznego z umieszczonymi na parterze sklepami i restauracją. „Przebudowany Stary Teatr jest więc jedną $\mathrm{z}$ pierwszych budowli u nas wykonaną przy wspótudziale sił artystycznych wszędzie, gdzie ich tylko użyć można bylo. Architektura bowiem wymaga takiego wspóludziału, wtenczas tylko nabiera życia, odrębności, wykończenia i istotnej wartości artystycznej" ${ }^{34}$. Józef Gardecki był autorem fryzu umieszczonego na budynku Starego Teatru: „umiejętne wprowadzenie ornamentu z elementów konstrukcyjnych, a także zręczne sfunkcjonalizowanie prac Gardeckiego spowodowało, że przebudowany Stary Teatr stał się przykładem dzieła łączącego różne sztuki w obrębie jednolitej kompozycj»"35.

Przy placu Szczepańskim nr 2 stały dawniej dwie średniowieczne kamienice, które w wieku XVIII były własnością kolegium jezuickiego przy parafii św. Szczepana, lecz w wyniku kasaty zakonu zostały zakupione przez Akademię Krakowską. Na jej miejscu w poł. XVIII w. postawiono nową kamienicę, którą nabyl Dominik Estreicher i pierwsze piętro kamienicy ozdobił freskami o tematyce antycznej. O tej kamienicy także wspomina A. Chmiel, pisząc o obrazach $€$. Kozakiewicza, iż była to dwupiętrowa kamienica o siedmiu oknach z wysokim dachem i altaną. W środku fasady umieszczono bramę. Część muru była z ciosanego kamienia i podobnie jak kamienica Starego Teatru pomalowana była na zielono ${ }^{36}$. W roku 1844 część pomieszczeń została przekazana Staremu Teatrowi, gdzie w ścianie granicznei znajdowało się specjalne przejście pomiędzy budynkami. W roku 1852 kamienica została sprzedana bankowi Kirchmajera, a w latach 1908-1909 zburzono i tę budując na tym terenie kamienicę dla przedsiębiorcy pogrzebowego, który na parterze tej kamienicy mial zakład pogrzebowy. Na pierwszym piętrze mieścił się Klub Literatów i Prawników. Budynek ten został wybudowany w stylu modernistycznym, zwieńczony wyniosłym dachem $\mathrm{z}$ oszkloną weranda. We wnętrzu znajduja się witraże zakładu S. G. Żeleńskiego, secesyjna winda, klatka schodowa z balustradami ozdobiona ceramicznymi płytkami, schodami i drzwiami ozdobionymi niezwykłą stolarką. Nad bramą główną znajduje się witraż ze św. Szczepanem, informujący o istnieniu w tym miejscu probostwa kościoła św. Szczepana. W rzeczywistości budynek probostwa wszedł w skład zabudowy Starego Teatru.

${ }^{33}$ Ł. Kozakiewicz z zawodu był malarzem pokojowym i dekoratorem Starego Teatru. W Księgach cechu malarskiego zapisana jest jedynie jego data śmierci, 21 VII 1845 r.; wtedy miał lat 63. Rysunki przedstawiające niektóre kamienice przy placu Szczepańskim podpisał jako material do panoramy Krakowa - A. C h m i e l, Plac Szczepański w Krakowie przed stu laty. Szkice Krakowskie, [w:] Biblioteka Krakowska nr 100, Kraków 1939-1947, s. 186.

${ }^{34}$ F. M ą c zy ń s k i, T. S t r y j e ń s k i, Stary Teatr, ,Architektura” 8(1907), s. 31-34.

${ }^{35} \mathrm{R}$. S olew ski, F. Maczyński i wspólnota sztuki miasta realizuje ideę "gesamtkustwerk” we wczesnej twórczości krakowskiego architekta, „Rocznik Krakowski” t. LXI 1995, s. 104.

${ }^{36}$ A. C h m i e 1, Plac Szczepański w Krakowie..., dz. cyt., s. 189-190. 
W kamienicy „Pod Panem Jezusem” na placu Szczepańskim 3 znajdował się szpital dla ubogich kupców oraz mieszczan krakowskich ufundowany przez trzech fundatorów. Dom ten wybudowano z połączenia dwóch średniowiecznych kamienic przed 1588 r. W 1628 r. biskup Marcin Szyszkowski przekazał uposażenie dla chorych. Tam również znajdowała się apteka $z$ infirmerią, w $1651 \mathrm{r}$. zapisano na nią sumę 5 tys. złotych, od której pobierano procenty na jej utrzymanie.

W miejscowej infirmerii i aptece praktykowali młodzi bracia zakonni. Kamienica ta przed poł. XVIII w. przeszła remont i zmianę wyposażenia. Na fasadzie były umieszczone rzeźby, obrazy religijne oraz krucyfiks. W 1817 r. szpital został przekazany Towarzystwu Dobroczynności, ${ }^{37}$ a rok później zamknięto go i przeniesiono na Wawel, a następnie do budynku Panien Koletek. O tej kamienicy także wspomina A. Chmiel, ponieważ ją również na swoich rysunkach umieścił Ł. Kozakiewicz. Kamienica ta miała dwie duże szkarpy na narożach, bramę umieszczoną w środku fasady, dwa wejścia do piwnic z ulicy. Drzwi były pochyło ustawione. Dach był mansardowy, kryty gontem. Fasadę kamienicy pomalowano wówczas na kolor piaskowy ${ }^{38}$. Budynek po przeniesieniu szpitala został zaadaptowany na cele mieszkalne, zaś w roku 1876 przekazany Towarzystwu Muzycznemu.

Przed rokiem 1890 r. przeprowadzono remont, a wkrótce budynek stał się własnością Romana Drobnera, który we wnętrzu otworzył restaurację. W ogrodzie kamienicy od strony Plant ustawiony został w 1904 r. dodatkowy pawilon, zwany później „Drobnerionem”, według projektu Jana Zawiejskiego, sygnowany przez prowadzącego prace budowlane Władysława Kleinbergera. O twórcy „Drobnerionu" śpiewano nawet w „Zielonym Baloniku”, a sam J. Zawiejski w niektórych swoich tekstach używał humorystycznego pseudonimu van Drobnersholm.

Był to przeszkolony, lekki pawilon z dwukondygnacyjną halla, parterowymi partiami bocznymi i weranda. Stylem nawiazywal do kawiarni wiedeńskich, o miękkich, falistych, secesyjnych liniach wzbogaconych motywami ludowymi i scenami dekoracyjnymi autorstwa Karola Frycza. Część środkowa pawilonu została podwyższona i posiadała dodatkową strefę okien. „Drobnerion” ozdobiony był ogromnym imbrykiem, jako godłem źródła tryskającego mokką. Po pożarze, w roku 1907, kawiarnię odbudował ze zmianami zwłaszcza w detalu W. Kleiberger już bez udziału J. Zawiejskiego, który ubolewał nad wprowadzonymi zmianami w wierszu Do Drobnerionu i Polskiej sztuki niestosównej ${ }^{39}$. Po śmierci R. Drobnera w 1913 r. piętro kamienicy zaadaptowano na kinoteatr „Wisła”, częściowo przebudowując obiekt. Po I wojnie światowej w tym budynku mieścił się lokal dancingowy „Polonia”, następnie kawiarnia „Udziałowa”. W 1918 r. znajdował się kabaret „Rozmaitości” Leona Wyrwicza. W roku 1927 budynek stał się własnością rodziny Szarskich, ale od nich wynajął go Jan Bisanz, który przywrócił budynkowi dawną świetność. Władze okupacyjne przejęły budynek w roku 1940. Odbywały się tu koncerty oraz funkcjonowało Volksdeutches Ringskasino, my-

37 Towarzystwo Dobroczynności było świecką organizacją charytatywną powołaną w 1816 r. przez Rząd Krajowy, kontynuującą tradycje średniowiecznego szpitalnictwa, oraz bractw miłosierdzia, zniesioną po II wojnie światowej - Encyklopedia Krakowa, Kraków 2002, s. 1000 .

${ }^{38}$ A. C h mi e l, Plac Szczepański w Krakowie..., dz. cyt., s. 189.

39 J. Purchla, Jan Zawiejski - architekt przetomu XIX i XX wieku, Warszawa 1986, s. 156 . 
ślano również w tym czasie o jego wyburzeniu. Do tego jednak nie doszło i po wojnie, w latach 1951-1952, przebudowana kamienica służyła na biura. W latach 1952-1956 otwarto w niej kawiarnię „Gastronom-Adria”, zaś od roku 1956 mieściła się tu kawiarnia Esplanda.

W 1960 r. budynek „Drobnerionu” calkowicie zburzono, a na jego miejscu wybudowano Biuro Wystaw Artystycznych.

W latach 90. XX w. gmach pod numerem 3 na placu Szczepańskim uzyskał nową fasadę. Do dziś kamienica ma dobrze zachowane średniowieczne mury, sklepienia piwnic oraz portale. Obecnie mieszczą się tu różne firmy i instytucje.

Na placu Szczepańskim nr 4 mieści się już wcześniej omawiany Pałac Towarzystwa Sztuk Pięknych, który stanął na działce nowicjatu OO. Jezuitów.

Pod numerem 5 na placu Szczepańskim wznosiła się niegdyś gotycka kamienica nazywana „Domem Esterki”, którą miał szczęście jeszcze umieścić na swym rysunku Ł. Kozakiewicz, a którą także wspomina A. Chmiel, opisując, ,iż z narożnika ul. św. Tomasza i ul. Reformackiej widać bok jednopiętrowej, wąskiej, dwuokiennej kamieniczki, biało tynkowanej i ganek drewniany z balaskami od strony podwórza"40. Już wtedy kamienica miała zniszczoną fasadę, a na dole znajdowały się dwa sklepiki. Obecnie na miejscu tej budowli od roku 1936 wznosi się tzw. Krakowski Drapacz Chmur, wybudowany dla Komunalnej Kasy Oszczędności. Po II wojnie światowej mieściła się w nim Komenda Milicji Obywatelskiej.

Tak zwana kamienica „Przechodnia” to z kolei budynek przy placu Szczepańskim nr 6. Do dziś jest ona zespołem dwupiętrowych połączonych zabudowań frontowych i dwóch oficyn. Pierwsze połączenie dwóch niezależnych parcel miało już miejsce w wieku XIV, ale zapełnione zostały dopiero w wieku XV. Pierwsza z kamienic należała do Falkowiczów - rzemieślników.

Wspólnego przekształcenia kamienic dokonano ok. 1595 r. dla złotnika wẹgierskiego o nazwisku Kolai, oficyna tylna została przebudowana i przekształcona w budynek mieszkalny. Wtedy też układ zewnętrzny został uzupełniony o klatkę schodowa.

W wieku XVI i XVII mieściła się tutaj mennica. Pomiędzy pierwszą a trzecią ćw. wieku XVII kamienica przeszła na własność wspomnianej wcześniej rodziny Falkowiczów. Następnie w wieku XVII, po najeździe szwedzkim, była remontowana. W roku 1696 otwarto furtkę na ulicę Reformacką na mocy testamentu rajcy krakowskiego Sebastiana Zacherli, by wiernym łatwiej było przechodzić do kościoła Reformatów.

W XVII w. budynek stał się własnością Zacherlów i Kikulinusów. W 1735 r. właścicielka tej kamienicy przekazała posesję na wybudowanie stacji Męki Pańskiej. W $1816 \mathrm{r}$ nrzehudowano oficyne Obecna fasada zostạa zanorojektowana w stylu modernistycznym $\mathrm{z}$ elementami secesji. Natomiast wschodnia część kamienicy „Przechodniej” zwana była Kolajowska, od nazwiska J. Kolaia, który był jej właścicielem od pierwszej ćwierci XVI w. W 1820 r. przeprowadzono gruntowny remont, wymieniając m.in. drewniane ściany. W roku 1824 wykupiona została przez właściciela o nazwisku Rajski, który scalił dwa budynki. W połowie XIX w. podwórko otoczyły budynki czynszowe. Kamienice te uległy jednak wyburzeniu i ponowne zlączenie dwóch parcel $i$ kamienic przeprowadzono w latach 1907-1910.

${ }^{40}$ A. C h m i e l, Plac Szczepański w Krakowie..., dz.cyt, s. 187. 
Kamienica Landauów pod numerem 7 na placu Szczepańskim to druga z połączonych posesji na tym placu. Była pierwotnie budynkiem o metryce średniowiecznej. Na przełomie XIV i XV w. wznosiła się tutaj murowana kamienica Leffarowska. W XVI w. została pogłębiona o trakt tylny $\mathrm{z}$ drewnianą elewacją. W pierwszej połowie XVII i XVIII przebudowano jej wnętrza i urządzono mieszkanie.

Od drugiej połowy XVI w. do XVIII był to dom rodziny rzemieślników i drobnych kupców o nazwisku Lefferowie. Przed 1771 r. przeprowadzono remont, a między 1771 r. a 1778 r. na przyłączonym fragmencie posesji urządzono ogródek. W latach 1881-1882 dokonano klasycystycznej przebudowy i zbudowano oficynę tylna w miejscu ogródka. W latach 1890-1892 właściciel Łukasz Landau przebudował i połączył neobarokową fasadą dwie kamienice. Znaczną jednak część murów wzniesiono od nowa, utrzymując układ wnętrz z wyjątkiem poszerzenia klatki schodowej. Następnie wyrównano poziomy pięter i założono nowy dach. W roku 1932 nastapila zmiana w parterze fasady. Zachowano jednak charakter kamienicy czynszowej $z$ wyposażeniem i dekoracją oraz drewniane ganki na podwórzu.

Do końca lat 80. funkcjonowała tutaj „Restauracja Myśliwska”, kontynuująca tradycję międzywojennej restauracji „Pietruszków” i XIX-wiecznej jadłodajni „Przed założeniem Kopca Kościuszki”.

Obok tej kamienicy stała jeszcze jedna, zwana Rurmistrzowska, Sędziwojowską, Miejską bądź Klauzmanowską. Murowany dom powstał w XIV w.

W XVI w. rozbudowano drewniany trakt tylny w 4 ćw. XVI w. posesję pogłębiono o działkę przy ul. Reformackiej. W tym czasie przeszła na własność Stanisława Rurmistrza (urzędnika miejskiego odpowiedzialnego za wodociagi). W drugiej ćwierci XVII w. była własnością alchemika Michała Sędziwoja. W XVII wieku została zaniedbana i przejęta przez miasto, jednak przed 1653 r. została odnowiona i w części przebudowana. W drugiej połowie XVII w. została zmodernizowana poprzez nadbudowanie dnugiego piętra przez następnego właściciela. W końcu XVII w. tylna część działki została odstapiona sąsiadom i włączona do Stacji Męki Pańskiej. W XVIII w. była własnością Szpitala Świętego Ducha. W 1804 r. została sprzedana na licytacji, a następnie wybudowano murowana, parterową oficynę boczną (wcześniej była to oficyna drewniana). W latach 1823-1825 dokonano klasycystycznej przebudowy i dopiero wówczas drewniany trakt zastapiono murowanym.

Kolejny budynek to gmach dzisiejszego Towarzystwa Rolniczego mieszczacy się pod numerem 8 na placu Szczepańskim. O poprzedniej kamienicy stojącej w tym miejscu wspomina A. Chmiel. Zwraca uwage, że ta kamienica miała główne wejście od ul. Żydowskiej(obecnie św. Tomasza). Była jednopiętrowa z siedmioma oknami.

Trzy okna z parteru miały umieszczone okiennice na zewnątrz, a jedno okno w środku fasady było przerobione na wejście sklepowe $\mathrm{z}$ drzwiami dwuskrzydłowymi. Za nimi miała znajdować się na prawo brama wjazdowa. Budynek był otynkowany na biało i miał położony gontowy dach ${ }^{41}$. W 1908-1909 wyburzono ja, a na jej miejscu stanęła obecna kamienica dawnego Towarzystwa Rolniczego wg. projektu Sławomira Odrzywolskiego i Władysława Kaczmarskiego z rzeźbami trzech męskich i czterech żeńskich figur, przedstawiających personifikacje prac rolnych. Umieszczono je pomiędzy oknami drugiego piętra.

${ }^{41}$ A. C h m i e l, Plac Szczepański w Krakowie..., dz. cyt, s. 188. 
Ostatnia kamienica na placu Szczepańskim znajduje się pod numerem 9, powszechnie znana jako kamienica Szołayskich. W XVI w. budynek był własnością mieszczańska. Od drugiej poł. XVII w. do końca XVIII należał do klasztoru Bożego Ciała. W XVIII w. popadł w ruinę. Później, w latach 1815-1818, powstał nowy, dwupiętrowy dom wybudowany przez ówczesnych właścicieli Marciszewskich. Przy jego budowie wykorzystano mury średniowiecznej zabudowy, które tworzyły narożnik ulicy Szczepańskiej i część cmentarza, jaki istniał wokół kościoła św. Szczepana. W tym stanie przedstawił ją 1 . Kozakiewicz na swoich rysunkach. Jak wyjaśnia A. Chmiel, kamienica ta miała po 9 okien na I i II piętrze, z gipsowymi obramowaniami. Na dole było jedno wejście boczne i 8 okien wychodzacych z pomieszczeń mieszkalnych. Wtedy była na biało otynkowana, nakryta gontowym dachem. Przy oknie narożnym parteru widoczna była tablica upamiętniająca nadanie nazwy Placu Gwardii Narodowej, która w tym miejscu istnieje do dziś ${ }^{42}$. W latach 1849-1856 w tym budynku mieściła się redakcja i drukarnia „Czasu”.

Od 1902 r. kamienica była własnością Włodzimiery i Adama Szolayskich, którzy przekazali ją w 1929 r. gminie miasta Kraków z przeznaczeniem na zbiory muzealne. W latach 30 . XX w. rozpoczą się proces adaptacji budynku pod Muzeum Narodowe. W 1955 r. zmieniono układ parteru, wymieniono kamieniarkę okien i zamieszczono neobarokowy portal.

Po wyburzeniu obu kościołów oraz budynku nowicjatu w roku 1802, plac Szczepański doświadczał wielu rozmaitych prób zmian i zrealizowanych działań na jego terenie. Po raz pierwszy za czasów austriackiego zaboru miejsce to próbowano wykorzystać pod koszary dla wojska, co zresztą zauważył S. Tomkowicz przy opisie planu Kołłątajowskiego z roku 1785: „na lewo widać budynek mieszkalny, dawniejszy dom Jezuitów - późniejsze koszary żołnierskie"43. Nazwe placu również próbowano zmienić, nadając mu w roku 1811 nazwę Placu Gwardii Narodowej. Tablicę z napisem: „Plac Gwardii Narodowej ogłoszony dnia 3 sierpnia 1811 roku" umieszczono na kamienicy Szolayskich od strony placu na pamiątkę utworzenia w Krakowie Gwardii Narodowej, do której należeli właściciele realności, kupcy, uczniowie, fabrykanci i rzemieślnicy. Na szczęście nazwa ta nie przyjęła się i powrócono do nazwy placu Szczepańskiego.

O wyglądzie placu Szczepańskiego wspomina Ambroży Grabowski, w jego tekach znajdują się również rysunki Ł. Kozakiewicza. Rysunki te moga pochodzić z roku 1824, jak i 1840, ,ponieważ do budynku Teatru nie jest włączona jedna kamienica, co nastapiło dopiero w 1840 , przy przebudowie teatru". Rysunki Kozakiewicza przedstawiaja plac osłonięty drewnianymi barierkami ${ }^{44}$.

W 1827 r plac wyłozono brukiem Nastennie w latach 1822-1823 na placu powstały jatki rzeźnicze, w ilości 98 drewnianych i 24 płóciennych, ustawionych w trzech rzędach, które zniesiono w 1823 r. Plac targowy był jeszcze widoczny $\mathrm{z}$ początkiem XX wieku.

W'́ród wielu pomysłów na zagospodarowanie placu powstal również projekt postawienia na placu Szczepańskim pomnika Legionów o kształcie ostrosłupa z figurami u podstawy, otoczonego łańcuchami i kamiennymi pachołkami. Próbo-

\footnotetext{
${ }^{42}$ A. Ch m i e l, Plac Szczepański w Krakowie..., dz. cyt, s. 188.

${ }^{43} \mathrm{~S}$. T o m k ow i c z, Plan Koltatajowski...,dz. cyt., s. 56

${ }^{44}$ A. Ch m i e I, Plac Szczepański w Krakowie..., dz. cyt, s. 186.
} 
wano także posadzić drzewka na placu i przekształcić go na park, ale próba ta nie powiodła się ze względu na zalegające pod stosunkowo niewielką ilością ziemi gruz i fundamenty wyburzonych kościołów. Na posiedzeniu Towarzystwa Technicznego w roku 1898 dyskutowano nad projektem zbudowania na placu hali targowej z wielkimi podziemiami, w których znalazłyby się sklepy różnych branż.

W roku 1978 zastanawiano się nad ustawieniem na placu pomnika Stanisława Wyspiańskiego, który ostatecznie posadowiono przed gmachem głównym Muzeum Narodowego. Od roku 1964 na placu Szczepańskim, w miejscu, gdzie przez kilka wieków mieściły się kościoły pod wezwaniem św. Szczepana i św. Macieja i Mateusza z cmentarzem, funkcjonuje parking samochodowy ${ }^{45}$.

Plac Szczepański jest jednym z najciekawszych miejsc Krakowa, aczkolwiek nieco zapomnianej historii, obrazującym liczne zmiany urbanistyczne miasta i odkrywającym wnikliwym badaczom niezwykłe tajemnice minionych wieków. Zadziwiające jest, że po wyburzeniu zabytkowych i wartościowych kościołów było tak wiele koncepcji zagospodarowania powstałej przestrzeni, ale żaden z projektów nie dawał godnego świadectwa miejscu o wyjątkowym charakterze, jakim jest plac Szczepański na mapie Krakowa. 